\title{
KUALITAS, HARGA DAN KERAGAMAN PRODUK TERHADAP LOYALITAS PELANGGAN
}

\author{
Zunita Rohmawati \\ Fakultas Ekonomi dan Bisnis \\ Universitas Muhammadiyah Gresik \\ Email: Zunitaumg@gmail.com
}

\begin{abstract}
Upaya-upaya pemasaran perlu dilakukan untuk dapat menciptakan loyalitas pelanggan, diantara upaya yang dapat dilakukan adalah dengan menciptakan produk berkualitas, menentukan harga, menyediakan layanan pada produk yang bervariasi, dengan demikian jika dilakukan akan diperoleh tujuan akhir dari proses pemasaran itu sendiri. Tujuan penelitian ini adalah penelitian Pengaruh Kualitas Produk, Harga dan Keragaman Produk Terhadap Loyalitas Pelanggan pada usaha Lily Bakery Lamongan, jumlah sampel yang digunakan sebanyak 100 responden yang pernah melakukan pembelian berulang pada usaha Lily Bakery. Teknik analisis yang digunakan dengan analisis regresi berganda dengan bantuan software SPSS. Hasil penelitian menunjukkan bahwa kualitas produk secara parsial berpengaruh positif dan signifikan terhadap loyalitas pelanggan, Harga secara parsial berpengaruh positif signifikan terhadap loyalitas pelanggan dan Keragaman produk secara parsial berpengaruh positif signifikan terhadap loyalitas pelanggan Lily Bakery Lamongan.
\end{abstract}

Keywords : Kualitas Produk, Harga dan Keragaman produk.

\section{PENDAHULUAN}

Perkembangan dunia usaha saat ini ditandai oleh bertambahnya jumlah pelaku usaha, sehingga ini membuat banyak pesaing berlomba-lomba menarik konsumen untuk menarik laba sebesarbesarnya. Dengan berkembangnya dunia usaha, kuliner pun menjadi salah satu trend usaha yang digandrungi dan diminati oleh masyarakat dan halayak. Sebanding dengan pemintaan konsumen yang semakin meningkat serta tingkat kejenuhan yang menuntut pebisnis untuk inovatif dan memiliki strategi-strategi yang baik.

Umumnya strategi lebih banyak didominasi oleh strategi pemasaran. Jadi bagaimana cara memasarkan produk-produk perusahaan kepada konsumen. Pemasaran berarti dapat menjaga konsumen untuk melakukan pembelian, atau menjaga image produk perusahaan agar tetap menjadi pilihan konsumen. begitu juga yang dilakukan oleh perusahaan Lily Bakery yang beralamat di Jl.Sunan Drajat No.67 Sidoharjo Lamongan yang bergerak dibidang kuliner khususnya cake \& bakery, Lily dikenal oleh masyarakat luas karena kualitas kue yang sangat enak dengan beraneka ragam kue dan harga yang sesuai dengan kualitas kue, serta pelayanan yang ramah banyak masyarakat yang tertarik membeli produk dan memutuskan untuk menjadi pelanggan tetap yang loyal pada lily bakery.

Upaya yang digunakan oleh Lily Bakery untuk menarik konsumen dan upaya -upaya yang dapat mempertahankan pelanggan atau dalam kata lain pelanggan dapat menjadi loyal terhadap produk dan toko. Oleh karena itu dalam melakukan upaya membuat pelanggan loyal dapat memperhatikan hal-hal seperti kualitas produk, harga dan keragaman produk atau variasi produk yang ditawarkan kepada konsumen.

Loyalitas Pelanggan adalah komitmen pelanggan bertahun-tahun secara mendalam untuk berlangganan kembali atau melakukan pembelian ulang produk atau jasa terpilih secara konsisten dimasa yang akan datang, meskipun pengaruh situasi dan usaha-usaha pemasaran mempunyai potensi untuk menyebabkan 
perubahan perilaku. Oliver (dalam Hurriyati, 2005:129)

Utami (2016:58) Loyalitas Konsumen berarti kesetiaan konsumen untuk berbelanja di lokasi ritel tertentu. Berdasakan beberapa dasar untuk mempertahankan keunggulan bersaing juga membantu menarik perhatian dan mempertahankan para konsumen yang loyal.

Kualitas produk sendiri sangatlah penting bagi suatu perusahaan. Kualitas produk merupakan faktor utama dalam perusahaan. Kualitas produk merupakan kebijakan penting dalam meningkatkan daya saing produk yang harus memberikan kepuasan kepada konsumen yang melebihi atau paling tidak sama dengan kualitas produk dari pesaing. Menurut Crosby 1997(dalam Na'in 2013) "kualitas produk adalah produk yang sesuai dengan yang diisyaratkan atau distandartkan. Suatu produk memiliki kualitas apabila sesuai dengan standart kualitas yang telah ditentukan".

Harga merupakan nilai uang yang seseorang butuhkan untuk memperoleh sejumlah produk dan pelayanan (Harini:2008). Harga merupakan konsep keanekaragaman yang memiliki arti berbeda bagi tiap konsumen, tergantung karakteristik konsumen, situasi dan produk (Munir:2005:46). Dengan kata lain, pada tingkat harga tertentu yang telah dikeluarkan, konsumen dapat merasakan manfaat dari produk yang telah dibelinya.

Keragaman produk merupakan keputusan mengenai kedalam dan kelebaran keragaman produk, variasi dari setiap produk serta kualitas produk tersebut. disamping keragaman produk yang menunjukan lebih banyak pilihan yang tersedia, kemungan terpenuhi kebutuhan pun lebih besar, sehingga para konsumen tidak perlu menghamburkan waktu dan tenaga untuk mencari produk yang diinginkan (Nugraha:2010). Dengan kualitas produk yang baik, harga yang terjangkau dan keragaman produk yang banyak diharapkan dapat menarik konsumen serta membuat konsumen loyal terhadap perusahaan.

Kualitas Produk dan Harga sangat berhungan dengan loyalitas pelanggan jika barang dan jasa dibeli cocok dengan apa yang diharapkan oleh konsumen, maka akan terdapat kepuasaan atau loyalitas dan sebaliknya. Menurut Goestch dan Davis (2000:04) dalam Nurhayati 2011 menyatakan bahwa "kualitas produk merupakan suatu kondisi dinamis yang dihubungkan dengan barang dan jasa, manusia, proses dari lingkungan yang memenuhi atau melebihi harapan".

Tjiptono (2000:54) menyebutkan bahwa kualitas suatu produk dan harga memiliki hubungan yang erat dengan kepuasan pelanggan untuk menjalin ikatan hubungan yang kuat dengan perusahaan, dalam jangka panjang, ikatan seperti ini memungkinkan perusahaan untuk memahami dengan seksama harapan pelanggan serta membutuhkan mereka. Selain kualitas produk dan harga, faktor lain yang mempengaruhi loyalitas pelanggan adalah keragaman produk. Banyak cara yang dapat ditempuh oleh perusahaan, khususnya Lily Bakery dalam mempertahankan dan meningkatkan loyalitas pelanggannya. Salah satu caranya adalah ragam produk yang disediakan oleh perusahaan. oleh karena itu, perusahaan harus membuat keputusan yang tepat mengenai keragaman produk yang dijual, karena dengan adanya macam-macam produk dalam arti produk yang lengkap mulai dari merk, ukuran, kualitas dan ketersediaan produk. Sesuai dengan pendapat Swastha dan Irawan (2002:122) dalam Cahyono (2012), faktor- faktor yang mempengaruhi loyalitas adalah harga, penggolongan dan keragaman barang, lokasi penjual yang strategis dan mudah dicapai, desain fisik toko, service yang ditawarkan pada pelanggan, kemampuan tenaga penjual dan pengiklanan serta promosi di toko. dengan adanya keragaman produk yang banyak maka akan memudahkan konsumen/pelanggan Lily Bakery dalam memilih dan membeli berbagai macam produk sesuai dengan keinginan mereka.

Memperhatikan keragaman produk perusahaan harus juga berupaya untuk memberikan pelayanan yang baik, sebab pelayanan yang berkualitas merupakan salah satu cara untuk menarik dan mempertahankan konsumen. Pelayanan harus diperhatikan karena 
dalam memilih suatu produk atau jasa konsumen selalu berupaya untuk memaksimalkan nilai yang dirasakan. Apabila konsumen merasa nilai yang dirasakan lebih tinggi daripada yang diharapkan maka konsumen akan merasa puas dan cenderung akan loyal. Berikut Data Jumlah Konsumen pada Lily Bakery.

Data tabel 1 menjelaskan bahwa toko tiap bulanya mengalami penurunan yang sangat banyak, jika hal tersebut dibiarkan terus menerus maka akan mengakibatkan kerugian yang sangat besar.

Tabel 1:Jumlah Konsumen Perbulan

\begin{tabular}{lll}
\hline Bulan & Jumlah Konsumen & $\begin{array}{l}\text { Rata-rata } \\
\text { pembelian }\end{array}$ \\
\hline 6 & 12.482 & 38.680 \\
\hline 7 & 12.210 & 48.804 \\
\hline 8 & 11.439 & 36.827
\end{tabular}

Sumber : Lily Bakery 2016

Data penurunan yang terjadi bisa disebabkan karena masalah harga dengan loyalitas pelanggan. Jika harga yang dicantumkan tidak sesuai dengan kualitas produk maka akan membuat semakin turunya loyalitas pelanngan, akan tetapi jika harga yang dilabel kan sesuai dengan kualitas produk maka akan meningkatkan loyalitas pelanggan, sehingga akan meminimalisir penurunan jumlah konsumen setiap bulannya. Dengan adanya permasalahan diatas peneliti tertarik untuk mengetahui sejauh mana kualitas produk, harga dan keragaman produk berpengauh terhadap loyalitas konsumen Lily Bakery Lamongan. Untuk itu penulis melakukan penelitian Pengaruh Kualitas Produk, Harga dan Keragaman Produk Terhadap Loyalitas Pelanggan Lily Bakery Lamongan

\section{KAJIAN PUSTAKA}

\section{Kualitas Produk}

Kualitas produk merupakan faktor utama dalam perusahaan. Kualitas produk merupakan kebijakan penting dalam meningkatkan daya saing produk yang harus memberikan kepuasan kepada konsumen yang melebihi atau paling tidak sama dengan kualitas produk dari pesaing.
Menurut Crosby 1997(dalam Na'in 2013) "kualitas produk adalah produk yang sesuai dengan yang diisyaratkan atau distandartkan. Suatu produk memiliki kualitas apabila sesuai dengan standart kualitas yang telah ditentukan".

Swastha dan handoko dalam Ahmad Fathoni (2016:2) menyebutkan faktor utama yang mempengaruhi loyalitas adalah citra merek, kualitas produk, kualitas pelayanan, kenyamanan (suasana toko), emosional faktor(nilai pelanggan) dan harga konsumen. Tjiptono (1995:24) Perusahaan dapat menarik pelanggan dan mengungguli pesaing mereka dengan mengenali, memenuhi, dan memuaskan kebutuhan pelanggannya dengan baik. Mendapatkan konsumen bukan berarti memiliki mereka. Mempertahankan konsumen tetap loyal justru lebih sulit dan ini dapat dicapai bila perusahaan terfokus pada kepuasan tinggi yang dirasakan pelanggannya. Dengan cara perusahaan untuk memenuhi kebutuhan pelanggan yang prima maka pelanggan akan merasakan kepuasan sehingga loyalitas pelanggan akan muncul dengan adanya kepuasan tersebut. Loyalitas pelanggan itu sendiri adalah keinginan kuat dari pelanggan untuk tetap membeli makanan pada toko Lily Bakery pada saat sekarang maupun masa depan.

\section{Harga}

Harga merupakan salah satu atribut penting yang dievaluasi oleh konsumen sehingga manajer perusahaan perlu benar-benar memahami peran tersebut dalam mempengaruhi sikap konsumen. Harga sebagai atribut dapat diartikan bahwa harga merupakan konsep keanekaragaman yang memiliki arti berbeda bagi tiap konsumen, tergantung karakteristik konsumen, situasi dan produk (Munir:2005:46). Dengan kata lain, pada tingkat harga tertentu yang telah dikeluarkan, konsumen dapat merasakan manfaat dari produk yang telah dibelinya. Persaingan dalam dunia usaha yang semakin meningkat pada gilirannya akan menjadikan harga menjadi salah satu strategi yang digunakan untuk memenangkan persaingan. Menurut pendapat Tjiptono (2006:54) menyebutkan bahwa kualitas produk dan harga 
memiliki hubungan yang erat dengan kepuasan pelanggan untuk menjalin ikatan hubungan yang kuat dengan perusahaan, dalam jangka panjang ikatan seperti ini memungkinkan perusahaan untuk memahami dengan seksama harapan pelanggan serta membutuhkan mereka.

\section{Keragaman Produk}

Keragaman produk adalah penciptaan produkproduk yang sedikit berbeda dari standart untuk memenuhi atau melengkapi kebutuhan dan keinginan konsumen. Karena adanya perbedaan perbedaan tersebut, perlu adanya keragaman produk agar selera, keinginan atau harapan konsumen dapat terpenuhi oleh produk. Adapun diferensiasi produk meliputi :

1. Bentuk produk

2. Variasi rasa

3. Daya tahan (expired)

4. Keistimewaan keragaman produk

Pada saat ini banyak perusahaan menyadari betapa pentingnya kesetiaan pelanggan. Banyak cara yang dapat ditempuh oleh perusahaan dalam rangka mempertahankan dan meningkatkan kesetiaan pelanggannya. Salah satu caranya adalah ragam produk yang disediakan oleh perusahaan.Oleh karena itu, perusahaan harus membuat keputusan yang tepat mengenai keragaman produk yang dijual, karena dengan adanya macam-macam produk dalam arti produk yang lengkap mulai dari merk, ukuran, kualitas dan ketersediaan produk.

\section{Loyalitas Pelanggan}

Griffin 2002 (dalam Na'in 2013) adalah "customer loyalty is behaviour based and is defined as non random purchase expessed oe time by some decision making unit". Sedangkan menurut Oliver (dalam Hurriyati, 2005: 129), loyalitas pelanggan adalah komitmen pelanggan bertahun-tahun secara mendalam untuk berlangganan kembali atau melakukan pembelian ulang produk atau jasa terpilih secara konsisten dimasa yang akan datang, meskipun pengaruh situasi dan usaha-usaha pemasaran mempunyai potensi untuk menyebabkan perubahan perilaku.

\section{METODOLOGI PENELITIAN}

Penelitian ini bersifat kausal (sebab-akibat) yaitu penelitian dengan memfokuskan pada beberapa variabel yang berhubungan (paradigma penelitian), merupakan pola pikir yang menunjukkan hubungan variabel yang akan diteliti yang sekaligus mencerminkan jenis dan jumlah rumusan masalah yang perlu dijawab melalui penelitian, teori yang digunakan untuk merumuskan hipotesis dan teknik analisis yang akan digunakan (Sugiyono,2010: 59).

Populasi dalam penelitian ini adalah Pelanggan Lily Bakery Lamongan, penelitian ini mengambil sampel dengan menggunakan teknik Nonprobability Sampling yang digunakan dalam penelitian ini adalah Sampling incidental. Mengenai hal ini, Arikunto (2010:183) menjelaskan bahwa Sampling incidental merupakan penentuan sampel berdasarkan kebetulan yaitu siapa saja yang secara kebetulan/incidental bertemu dengan peneliti dapat digunakan sebagai sampel. Sampel yang akan digunakan dalam penelitian ini adalah 100 responden yang melakukan pembelian pada Lily Bakery Lamongan. Ukuran sampel yang digunakan dalam penelitian ini adalah jumlah minimal sampel dalam analisis multivariat.

Sumber data yang digunakan dalam penelitian ini adalah data primer dan sekunder. Data primer merupakan sumber data yang diperoleh langsung dari sumber asli dari hasil penyebaran kuesioner berisi tentang Pengaruh Kualitas Produk, Harga Dan Keragaman Produk Terhadap Loyalitas Pelanggan Lily Bakery Lamongan. Data sekunder adalah data yang didapat secara tidak langsung yang didapat dari buku dan sumber penelitian pada Lily Bakery Lamongan.

Identifikasi variabel dan definisi operasional variabel, variabel adalah segala sesuatu yang berbentuk apa saja yang ditetapkan oleh peneliti untuk dipelajari sehingga diperoleh informasi tentang hal tersebut, Variabel-variabel yang digunakan dalam"Pengaruh kualitas Produk, Harga dan Keragaman Produk Terhadap Loyalitas Pelanggan Lily Bakery Lamongan"adalah: 
1. Variabel Kualitas Produk $\left(\mathrm{X}_{1}\right)$

Kualitas produk adalah kegiatan yang dilakukan oleh Lily Bakery Lamongan dalam meningkatkan kualitas hasil atau produk guna memuaskan para konsumen. Kualitas produk memilki indikator sebagai berikut:
a. Kualitas Rasa
b. Ciri khas / keistimewaan
c. Suistaibility (Kesesuaian)

2. Variabel Harga $\left(X_{2}\right)$

Harga Adalah sejumlah uang yang dibebankan atas suatu produk atau jasa, atau jumlah dari nilai yang ditukar konsumen atas manfaat-manfaat karena memiliki atau menggunakan produk atau jasa tersebut. Adapun indikator adalah:

a. Terjangkaunya atau tidaknya harga.

b. Kecocokan antara harga dengan kualitas.

c. Kemudahan cara pembayaran.

3. Variabel keragaman Produk (X3)

Keragaman produk adalah penciptaan produkproduk yang sedikit berbeda dari standart untuk memenuhi atau melengkapi kebutuhan dan keinginan konsumen. Karena adanya perbedaan - perbedaan tersebut, perlu adanya keragaman produk agar selera, keinginan atau harapan konsumen dapat terpenuhi oleh produk.
a. Bentuk produk
b. Variasi rasa
c. Dayatahan / expired
d. Keistimewaan

4. Variabel Loyalitas Pelanggan (Y)

Loyalitas pelanggan adalah komitmen pelanggan bertahun-tahun secara mendalam untuk berlangganan kembali atau melakukan pembelian ulang produk atau jasa terpilih secara konsisten dimasa yang akan datang, meskipun pengaruh situasi dan usaha-usaha pemasaran mempunyai potensi untuk menyebabkan perubahan perilaku. indikatornya adalah:

a. Merekomendasikan kepada teman.

b. Tidak ingin pindah ke toko bakery lain. c. Menjadi pelanggan lily adalah pilihan yang tepat.

Pengukuran dari tiap variabel dilakukan dengan alat bantu menggunakan skala likert. Menurut Sugiyono (2010:93) menyatakan bahwa skala likert digunakan untuk mengukur sikap, pendapat, dan persepsi seseorang atau sekelompok orang tentang fenomena sosial. Dalam penelitian, fenomena sosial ini telah ditetapkan secara spesifik oleh peneliti yang selanjutnya disebut sebagai variabel penelitian.

Dengan skala likert, maka variabel yang akan diukur dijabarkan menjadi indikator variabel. Kemudian indikator tersebut dijadikan sebagai titik tolak untuk menyusun item-item instrumen yang dapat berupa pernyataan atau pertanyaan. Pengujian instrumen menggunkanakan, pertama uji validitas digunakan untuk mengukur sah atau valid tidaknya suatu kuesioner. Suatu kuesioner dikatakan valid jika pertanyaan pada kuesioner mampu untuk mengungkapkan suatu yang akan diukur oleh kuesioner (Ghozali, 2005;45). Cara pengukuran validitas angket kompetensi menggunakan teknik korelasi dengan $r$ pearson atau koefisien korelasi product moment pearson dengan taraf signifikan 5\%. Dasar pengambilan keputusan untuk menguji validitas butir angket adalah jika $\mathrm{r}$ hitung $>\mathrm{r}$ tabel maka butir atau variabel tersebut valid. Sebaliknya jika $r$ hitung < $\mathrm{r}_{\text {tabel }}$ maka butir atau variabel tersebut tidak valid. Uji instrument kedua, Uji reliabilitas adalah data untuk mengukur kuesioner yang merupakan indicator dari variabel. Suatu kuesioner dikatakan reliable atau handal jika jawaban seseorang terhadap pernyataan adalah konsisten atau stabil dari waktu ke waktu. SPSS memberikan fasilitas untuk mengukur reliabilitas dengan uji statistic cronbach alpha $(\alpha)$. Suatu konstruk atau variabel dikatakan reliable jika statistic cronbach alpha $(\alpha)>0,70$ (Ghozali,2010;41).

Pengujian model regresi yang baik (BLUE) digunakan beberapa uji diantaranya; 1) Uji normalitas bertujuan untuk menguji apakah dalam model regresi, variabel pengganggu atau residual memiliki distribusi normal. Kalau nilai 
residual tidak mengikuti distribusi normal, uji statistik menjadi tidak valid untuk jumlah sample kecil (Ghozali, 2013:160) Salah satu cara termudah untuk melihat normalitas residual adalah dengan melihat grafik histogram yang membandingkan antara data observasi dengan distibusi yang mendekati distribusi norml, namun demikian hanya dengan melihat histogram hal ini dapat menyesatkan khususnya untuk jumlah sampel yang kecil. Metode yang lebih handal adalah dengan melihat normal probability plot yang membandingkan distribusi kumulatif dari distribusi normal. Distribusi normal akan membentuk satu garis lurus diagonal, dan ploting data residual akan dibandingkan dengan garis diagonal. Jika distribusi data residual normal maka garis yang menggambarkan data sesungguhnya akan mengikuti garis diagonalnya; 2)

Uji multikolinearitas bertujuan untuk menguji apakah model regresi ditemukan adanya korelasi antar variabel bebas atau independent. Model regresi yang baik seharusnya tidak terjadi korelasi diantara variabel independent (Ghozali, 2013:105). Uji multikolinieritas ini dilakukan dengan melihat nilai Variance Inflation Faktor (VIF). Nilai cuf off yang umum dipakai untuk menunjukkan adanya multikolinieritas adalah nilai tolerance $<0,10$ atau sama dengan VIF $>10$ (Ghozali, 2013:106); 3) Uji heteroskedastisitas yang bertujuan menguji apakah dalam model regresi terjadi ketidaksamaan variance dari residual satu pengamatan ke pengamatan yang lainnya. Jika variance dari residual satu pengamatan ke pengamatan lain tetap, maka disebut homoskedastisitas. Jika variance tersebut berbeda, maka disebut heteroskedastisitas. Model regresi yang baik adalah yang homoskedastisitas atau tidak terjadi heteroskedastisitas Ghozali (2011;105). Bahwa Gejala heteroskedastisitas terjadi sebagai akibat ketidaksamaan data, terlalu bervariasinya data yang diteliti. Ada beberapa cara untuk mendeteksi ada atau tidaknya heteroskedastisitas Ghozali, (2011;105) salah satunya yaitu dengan melihat grafik plot antara nilai prediksi variabel dependen dengan residualnya. Dasar analisisnya adalah:
1. Jika terdapat pola tertentu, seperti titik-titik yang ada membentuk pola tertentu yang teratur (bergelombang, melebar kemudian menyempit) maka mengindikasikan telah terjadi heteroskedastisitas.

2. Jika tidak ada pola yang jelas, serta titik-titik menyebar di atas dan di bawah angka 0 (nol) pada sumbu Y, maka tidak terjadi heteroskedastisitas.

Teknik Analisis Data dalam penelitian ini adalah menggunakan analisis regresi berganda, yang merupakan studi mengenai ketergantungan variabel terikat dengan satu atau lebih variabel bebas dengan tujuan untuk memprediksi nilai rata-rata variabel terikat berdasarkan nilai variabel bebas yang diketahui Gozhali, (2011:43).

Persamaan garis regresi linier berganda dapat ditulis sebagai berikut:

$\mathrm{Y}=\mathrm{a}+\mathrm{b}_{1} \mathrm{X}_{1}+\mathrm{b}_{2} \mathrm{X}_{2}+\mathrm{b}_{3} \mathrm{X}_{3}+\mathrm{e}$

Dimana:

$\mathrm{Y}=$ Loyalitas Pelanggan

$\mathrm{a}=$ Nilai Konstanta

$\mathrm{X}_{1}=$ Kualitas Produk

$\mathrm{X}_{2}=$ Harga

$\mathrm{X}_{3}=$ Keragaman Produk

$b_{1}=$ Koefisien regresi dari $X_{1}$

$b_{2}=$ Koefisien regresi dari $X_{2}$

$\mathrm{b}_{3}=$ Koefisien regresi dari $\mathrm{X}_{3}$

$\mathrm{e}=$ Error

Uji Hipotesis penelitian ini menggunakan Uji t (parsial), dimana uji ini digunakan untuk menguji seberapa jauh satu variabel bebas (independen) secara individual dalam menerangkan variasi variabel terikat (dependen).

\section{HASIL DAN PEMBAHASAN}

Pengujian tahap awal sebelum dilakukan pengujian regresi dilakukan pengujian-pengujian sebagai berukut:

\section{Uji Validitas}

Uji validitas digunakan untuk mengukur sah atau valid tidaknya suatu kuesioner. Suatu kuesioner dikatakan valid jika pertanyaan pada kuesioner mampu untuk mengungkapkan suatu yang akan diukur oleh kuesioner (Ghozali, 2005;45). Cara 
pengukuran validitas angket kompetensi menggunakan teknik korelasi dengan $r$ pearson atau koefisien korelasi product moment pearson dengan taraf signifikan 5\%. Dasar pengambilan keputusan untuk menguji validitas butir angket adalah jika $r$ hitung $>r$ tabel maka butir atau variabel tersebut valid.Sebaliknya jika $r$ hitung $<r$ tabel maka butir atau variabel tersebut tidak valid. Nilai $r$ tabel yang digunakan adalah 0.1966. Hasil Uji dapat dilihat pada tabel 2 sebagai berikut:

Berdasarkan tabel 2 menunjukkan bahwa seluruh item kuesioner dinyatakan valid.Hal ini ditujukkan oleh semua item pernyataan menunjukkan $r_{\text {hitung }}>r_{\text {tabel }} 0,1966$, Jadi seluruh item pertanyaan dari variabel independen maupun dependen terbukti valid.

\section{Uji Reliabilitas}

Uji Reliabilitas adalah data untuk mengukur suatu kuesioner yang merupakan indikator dari variabel.Suatu kuesioner dikatakan reliable atau handal jika jawaban seseorang terhadap pernyataan adalah konsisten atau stabil dari waktu ke waktu

Tabel 2: Hasil Uji Validitas

\begin{tabular}{llc}
\hline \multicolumn{1}{c}{ Variabel } & r hitung & Ket \\
\hline Kualitas produk $\left(\mathrm{X}_{1}\right)$ & & \\
\hline $\mathrm{X} 1.1$ & 0,723 & Valid \\
\hline $\mathrm{X} 1.2$ & 0,773 & Valid \\
\hline $\mathrm{X} 1.3$ & 0,651 & Valid \\
\hline Harga $\left(\mathrm{X}_{2}\right)$ & & \\
\hline $\mathrm{X} 2.1$ & 0,584 & Valid \\
\hline $\mathrm{X} 2.2$ & 0,694 & Valid \\
\hline $\mathrm{X} 2.3$ & 0,699 & Valid \\
\hline Keragaman produk $\left(\mathrm{X}_{3}\right)$ & & \\
\hline $\mathrm{X} 3.1$ & 0,641 & Valid \\
\hline $\mathrm{X} 3.2$ & 0,554 & Valid \\
\hline $\mathrm{X} 3.3$ & 0,555 & Valid \\
\hline $\mathrm{X} 3.4$ & 0,729 & Valid \\
\hline Loyalitas pelanggan $(\mathrm{Y})$ & & \\
\hline Y.1 & 0,786 & Valid \\
\hline Y.2 & 0,716 & Valid \\
\hline Y.3 & 0,672 & Valid \\
\hline Sunber Hasil Olah Data &
\end{tabular}

Sumber: Hasil Olah Data

SPSS memberikan fasilitas untuk mengukur reliabilitas dengan uji statistic Cronbach Alpha $(\alpha)$. Suatu konstruk atau variabel dikatakan reliable jika statistic Cronbach Alpha $(\alpha)>0,70$ (Ghozali, 2005:41).Hasil Uji dapat dilihat pada tabel 3.

Tabel 3: Hasil Uji Reliabilitas

\begin{tabular}{lll}
\hline Variabel & $\begin{array}{l}\text { Cronbach } \\
\text { alpha }\end{array}$ & Simpulan \\
\hline $\mathrm{X} 1$ & 0,781 & Reliabel \\
\hline $\mathrm{X} 2$ & 0,744 & Reliabel \\
\hline $\mathrm{X} 3$ & 0,736 & Reliabel \\
\hline $\mathrm{Y}$ & 0,788 & Reliabel \\
\hline
\end{tabular}

Sumber : Data diolah

Berdasarkan tabel 3 menunjukkan bahwa variabel bebas dan variabel terikat mempunyai nilai Cronbachalpha> 0,70. Jadi pertanyaan seluruhnya dianggap reliabel atau handal dalam melakukan fungsinya sebagai alat ukur.

\section{Uji Normalitas}

Uji normalitas bertujuan untuk menguji apakah dalam model regresi, variabel pengganggu atau residual memiliki distribusi normal atau tidak, salah satu cara termudah untuk melihat normalitas adalah dengan melihat normal probability plot yaitu membandingkandistribusi kumulatif dari data sesungguhnya dengan distribusikumulatif dari distribusi normal. Distribusi normal akan membentuk satu garis lurus diagonal, dan ploting data residual akan dibandingkan dengan garis diagonal. Jika distribusi data residual normal, maka garis yang menggambarkan data sesungguhnya akan mengikuti garis diagonalnya (Ghozali, 2013;160), hasilnya sebagai berikut :

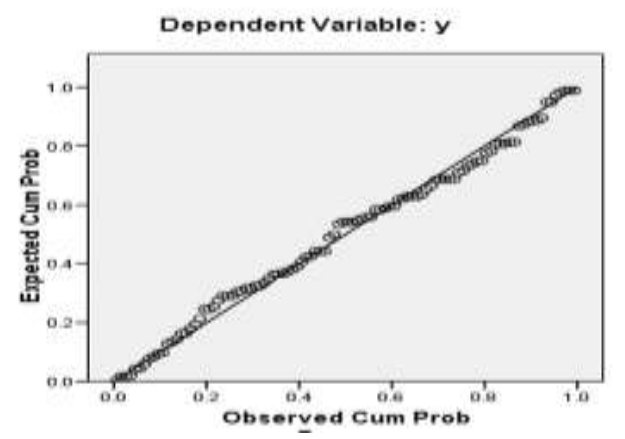

Sumber : data diolah

Gambar 1: Uji Normalitas Normal Probability Plot 
Hasil grafik Normal P-P Plot terlihat titiktitik menyebar disekitar garis diagonal dan mengikuti arah garis diagonal, jadi dapat disimpulkan bahwa variabel penelitian ini menunjukkan bahwa model regresi memenuhi asumsi normalitas.

\section{Uji Multikolinieritas}

Uji multikolinearitas bertujuan untuk menguji apakah model regresi ditemukan adanya korelasi antar variabel bebas atau independent.Model regresi yang baik seharusnya tidak terjadi korelasi diantara variabel independent (Ghozali, 2013:105).Uji multikolinieritas ini dilakukan dengan melihat nilai Variance Inflation Faktor (VIF). Nilai cuf off yang umum dipakai untuk menunjukkan adanya multikolinieritas adalah nilai tolerance $<0,10$ atau sama dengan VIF $>10$ (Ghozali, 2013:106).Untuk mendeteksi ada atau tidaknya multikolonearitas, Berdasarkan hasil uji multikolinearitas pada tabel 4.11 di atas, Dari hasil pengelolaan data diperoleh nilai tolerance value kualitas produk 0.552 , harga 0.570 , keragaman produk 0.828 dan dapat dilihat bahwa semua variabel independen memiliki nilai VIF < 10 yaitu pada kualitas produk 1.812, harga 1.756 , keragaman produk 1.208 . dengan demikian maka dapat disimpulkan bahwa tidak terjadi kolerasi diantara variabel-variabel independen yang diuji.

\section{Uji Heteroskedastisitas}

uji heteroskedastisitas bertujuan untuk menguji apakah dalam model regresi tejadi ketidaksamaan varians dan residu satu pengamatan ke pengamatan yang lain.jikavarians dan residu satu pengamatan ke pengamatan yang lain tetap, maka disebut homokedastisitas dan jika berbeda disebut heteroskedastisitas. Model egesi ang baik adalah yang homokedastisitas atau tidak tejadi heteroskedastisitas.untuk melakukan pengujian tehadap asumsi inidilakukan dengan menggunakan analisis dengan grafik plots.apabila titik-titik menyebar secara acak baik diatas maupun dibawah nol pada sumbu Y maka dinyatakan tidak tejadi heteroskedastisitas, menurut (Ghozali 2007), jika ada pola tertentu, seperti titik-titik yang membentuk pola tertentu yang teratur, maka mengindikasi telah terjadiheteroskedastisitas. Hasil menunjukkan tidak terdapat pola yang jelas dari titik-titik tersebut.hal ini menunjukan bahwa model regresi tidak memiliki gejala adanya heteroskedastisitas, yang berarti bahwa tidak ada gangguan yang berarti dalam model regresi ini.

\section{Analisis Regresi Linier Berganda}

Analisis regresi berganda digunakan untuk mengukur pengaruh/hubungan variabel independen dengan variabel dependen.Hasil dari analisis regresi linier berganda mengenai pengaruh kualitas produk, harga dan keragaman produk terhadap loyalitas pelanggan pada Lyly Bakery dapat dilihat dari Tabel 4.

Tabel 4. Hasil Analisis Regresi Linier Berganda

\begin{tabular}{lll}
\hline \multicolumn{1}{c}{$\begin{array}{c}\text { Model } \\
\text { (1) }\end{array}$} & \multicolumn{2}{c}{ Unstandardized coeficients } \\
\cline { 2 - 3 } Constant & .796 & Std Error \\
\hline $\mathrm{X} 1$ & .208 & 1.217 \\
\hline $\mathrm{X} 2$ & .294 & .104 \\
\hline $\mathrm{X} 3$ & .325 & .080 \\
\hline
\end{tabular}

Dependent Y

$Y=0,796+0,208 X_{1}+0,294 X_{2}+0,325 X_{3}+e$

Keterangan:

$\begin{array}{ll}\mathrm{Y} & : \text { Loyalitas Pelanggan } \\ \alpha & : \text { Konstanta } \\ \mathrm{X}_{1} & : \text { Kualitas Produk } \\ \mathrm{X}_{2} & : \text { Harga } \\ \mathrm{X}_{3} & : \text { Keragaman Produk }\end{array}$

Berdasarkan tabel 4, maka dapat diperoleh persamaan regresi berganda adalah sebagai berikut :

1. Nilai Konstanta (a) sebesar 0,796 artinya jika Kualitas Produk $\left(\mathrm{X}_{1}\right)$, Harga $\left(\mathrm{X}_{2}\right)$ dan Keragaman Produk $\left(\mathrm{X}_{3}\right)$ bernilai 0 , maka Loyalitas Pelanggan (Y) nilainya 0,796.

2. Jika Variabel Kualitas Produk $\left(\mathrm{X}_{1}\right)$ berubah dengan satu satuan nilai, maka $\mathrm{Y}$ akan 
berubah sebesar 0,208 satuan. Dengan anggapan Harga $\left(\mathrm{X}_{2}\right)$ danKeragaman Produk $\left(\mathrm{X}_{3}\right)$ tetap.

3. Jika Harga $\left(X_{2}\right)$ berubah dengan satu satuan nilai, maka Y akan berubah sebesar 0,294 satuan nilai dengan anggapan Kualitas Produk $\left(\mathrm{X}_{1}\right)$ dan Keragaman $\operatorname{Produk}\left(\mathrm{X}_{3}\right)$ tetap.

4. JikaKeragaman Produk $\left(\mathrm{X}_{3}\right)$ berubah dengan satu satuan nilai, maka $\mathrm{Y}$ akan berubah sebesar 0,325 satuan nilai dengan anggapan Kualitas Produk $\left(\mathrm{X}_{1}\right)$ dan Harga $\left(\mathrm{X}_{2}\right)$ tetap.

\section{Koefisien Determinasi (Adjusted $\boldsymbol{R}^{2}$ )}

Koefisien determinasi $\left(\mathrm{R}^{2}\right)$ pada intinya mengukur seberapa jauh kemampuan model dalam menerangkan variasi variabel terikat.Nilai koefisien determinasia dalah di antara nol dan satu. Nilai $\mathrm{R}^{2}$ yang kecil berarti kemampuan variabel-variabel independen dalam menjelaskan variasi variabel dependen ama tterbatas. Nilai yang mendekati satu berarti variabel-variabel independen memberikan hamper semua informasi yang dibutuhkan untuk memprediksi variasi variabel dependen (Ghozali, 2013;100). Hasil pengujian hipotesis dengan menggunakan Koefisien determinasi $\left(\mathrm{R}^{2}\right)$ dapat dilihat pada tabel 5 berikut:

Tabel 5:KoefisienDeterminasi (Adjusted $R^{2}$ )

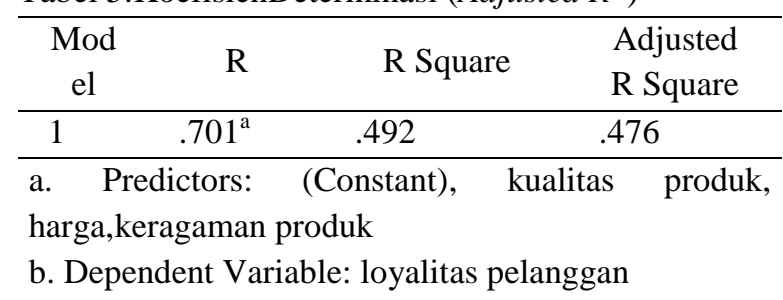

1. Berdasarkan data diatas maka diperoleh nilai Adjusted R Square = 0,476 dapat dikatakan bahwa perubahan variabel terikat Loyalitas Pelanggan (Y) sebesar 47,6\% disebabkan oleh variabel Kualitas Produk $\left(\mathrm{X}_{1}\right)$, Harga $\left(\mathrm{X}_{2}\right)$ dan Keragaman Produk $\left(\mathrm{X}_{3}\right)$ sedangkan selebihnya dapat dijelaskan oleh faktorfaktor lain diluar variabel tersebut.

2. Berdasarkan data diatas maka diperoleh nilai R Square $=0,492$ artinya bahwa perubahan dalam variabel terikat Loyalitas Pelanggan
(Y) dapat dijelaskan oleh perubahanperubahan dalam variable Kualitas Produk $\left(\mathrm{X}_{1}\right)$, Harga $\left(\mathrm{X}_{2}\right)$ dan Keragaman Produk $\left(\mathrm{X}_{3}\right)$ sebesar $49,2 \%$ sedangkan selebihnya dapat dijelaskan oleh faktor-faktor lain diluar variabel tersebut.

$\mathrm{R}=0,701$ artinya kuatnya hubungan antar variabel independen $(\mathrm{X})$ bersama-samater hadap variabel (Y) yaitu 70,1\%.

\section{Uji Hipotesis}

Uji ini digunakan untuk menguji pengaruh satu variabel bebas (independen) secara individual dalam menerangkan variasi variabel terikat (dependen). Hasil uji sebagai berikut:

Dari table 6 diatas hasil penelitian menunjukan bahwa variabel Kualitas $\operatorname{Produk}\left(\mathrm{X}_{1}\right)$ terbukti berpengaruh positif dan signifikan terhadap Loyalitas Pelanggan, variabel $\operatorname{Harga}\left(\mathrm{X}_{2}\right)$ terbukti berpengaruh positif dan signifikan terhadap Loyalitas Pelanggan dan variabel Keragaman Produk $\left(\mathrm{X}_{3}\right)$ terbukti berpengaruh positif dan signifikan terhadap Loyalitas Pelanggan

Tabel 6: Hasil Uji Hipotesis

\begin{tabular}{llll}
\hline Pengaruh & Nilai & Simpulan \\
\hline $\begin{array}{l}\text { Kualitas } \\
\text { Produk } \rightarrow \text { Loyalitas }\end{array}$ & .047 & Mendukung \\
\hline Harga $\rightarrow$ Loyalitas & & .010 & Mendukung \\
\hline $\begin{array}{l}\text { Keragaman Produk } \\
\text { Loyalitas }\end{array}$ & $\rightarrow$ & .000 & Mendukung \\
\hline
\end{tabular}

Sumber: Data Diolah

\section{Pembahasan}

Berdasarkan penelitian dan analisis yang peneliti olah dengan menggunkan alat bantuan SPSS 21 for windows maka peneliti dapat menginterprestasikan hasil sebagai berikut :

1. Menurut hasil perhitungan diperoleh t hitung 2.010 lebih besar dari t-tabel sebesar 1,9847, maka Ho ditolak. Sehingga dapat dimbil kesimpulan bahwa variable Kualitas produk berpengaruh positif dan signifikan terhadap Loyalitas Pelanggan,menurut Swastha dan Handoko dalam Ahmad Fatoni terbukti (2016:02). 
2. Menurut hasil perhitungan diperoleh t-hitung 2.2622 sedangkan t-tabel sebesar 1,9847, maka maka Ho ditolak. Sehingga dapat dimbil kesimpulan bahwa variable Harga berpengaruh positif dan signifikan terhadap Loyalitas Pelanggan, menurut Swastha dan Irawan dalam Dwi cahyono (2002:122)terbukti.

3. Menurut hasil perhitungan diperoleh t-hitung 4.057 lebih besar dari t-tabel sebesar 1,9847, maka Ho diterima. Sehingga dapat dimbil kesimpulan bahwa variable Keragaman Produk berpengaruh positif dan signifikan terhadap Loyalitas Pelanggan, menurut Swastha dan Irawan dalam Dwi cahyono (2002:122) terbukti.

4. Nilai koefisien korelasi Adjusted R Square sebesar0,476 dimana dengan nilai tersebut hubungan antar variabel bebas dengan variabel terikat sebesar47,6 \%, artinyaLoyalitas Pelanggan mempengaruhi dan mempunyai hubungan korelasi kuat dengan variabel Kualitas Produk (X1), Harga (X2), dan Keragaman Produk (X3)sebesar47,6\%.Koefisien determinan R Square dari data diatas adalah 0,492 atau $49,2 \%$, artinya bahwa dalam variabel terikat (Kinerja Pegawai) dapat dijelaskan oleh variable-variabelKualitas Produk (X1), Harga (X2), dan Keragaman Produk (X3)sebesar49,2\%. $\mathrm{R}=0,701$ artinya lemahnya hubungan antar variabel independent (X) bersama-sama terhadap variabel dependent yaitu70,1\%.VariabelKualitas Produk, harga, dankeragaman produkmerupakan hal yang paling berpengaruh keragaman produk dengan banyaknyak varian rasa membuat pelanggan loyal terhadap Lily Bakery.

\section{SIMPULAN}

Berdasarkan hasil analisis data dan interprestasi hasil maka kesimpulan yang diambil dari penelitian dengan judul pengaruh kualitas produk, harga dan keragaman produk terhadap loyalitas pelanggan Lily Bakery Lamongan" adalah sebagai berikut :
1. Kualitas produk secara parsial berpengaruh positif dan signifikan terhadap loyalitas pelanggan Lily Bakery Lamongan.

2. Harga secara parsial berpengaruh positif signifikan terhadap loyalitas pelanggan Lily Bakery Lamongan.

3. Keragaman produk secara parsial berpengaruh positif signifikan terhadap loyalitas pelanggan Lily Bakery Lamongan.

Berdasarkan hasil pengujian hipotesis $t$ yang dilakukan peneliti variabel Kualitas produk memperoleh nilai yang paling rendah dibandingkan dengan variabel harga dan keragaman produk maka peneliti memberikan rekomendasi sebagai berikut: 1) Keragaman produk memiliki koefisien parsial (Uji t) terbesar, sebaiknya harus dipertahankan dan di perbanyak varian rasa produk baru, menampilkan produk yang menarik, serta desain produk yang baik supaya pelanggan puas dan loyal terhadap Lily Bakery; 2) Berdasarkan Variabel harga dengan memberikan harga yang terjangkau maka pelanggan akan loyal tehadap Lily Bakery; 3) Variabel kualitas produk memiliki nilai yang rendah maka sebaiknya produk yang ditawarkan oleh Lily Bakery harus dapat memiliki kualitas produk yang unggul dan sesuai dengan harapan konsumen dan menggunakan bahan bahan baku yang berkualitas supaya pelanggan akan puas dan loyal terhadap Lily Bakery.

Bagi peneliti selanjutnya hasil penelitian ini dapat digunakan sebagai bahan referensi peneliti selanjutnya dengan memperbanyak atau menambah beberapa jumlah variabel-variabelnya dan menggunakan teknik analisis yang berbeda, dengan harapan agar peneliti selanjutnya dapat lebih baik hasilnya dari peneliti sebelumnya serta berguna bagi tempat penelitian selanjunya.

\section{DAFTAR PUSTAKA}

Arikunto,Suharsimi.2010. Prosedur Penelitian. Jakarta; Rineka Cipta

Cahyono, Dwi. 2012 ,"Pengaruh Kualitas Produk Dan Nilai Pelanggan Terhadap Loyalitas Pelanggan Skripsi Fakultas Ekonomi Universitas Muhammadiyah Gresik. 
Fatoni, Ahmad. 2016,"Pengaruh Kualitas Produk,Kualitas Layanan,Citra Merek Dan Nilai Pelanggan Terhadap Loyalitas Pelanggan Warung Apung Rahmawati Gresik" Skripsi Fakultas Ekonomi Universitas Muhammadiyah Gresik.

Kotler, Philip. 2009. Manajemen Pemasaran. Jakarta : Erlangga

------ dan Kevin Lane Keller, 2008. Manajemen Pemasaran. Jilid Satu, Edisi Kesepuluh, Cetakan Ketiga. Penerbit Indeks.

------ dan Kevin Lane Keller. 2009. Manajemen Pemasaran Jilid 2, edisi Ketiga Belas, Terjemahan Bob Sabran, MM. Jakarta: Penerbit Erlangga.

-------, dan Amstrong. 2001. Prinsip-Prinsip Pemasaran. Jilid Satu, Edisi Kedelapan, Jakarta : Erlangga.

Ghozali, Imam. 2011. Aplikasi Analisis Multivariates Dengan Program SPSS. Semarang: Badan Penelitian Universitas Diponegoro.

Nain Mochamad. 2013, "pengaruh ekuitas merek kualitas produk dan harga terhadap loyalitas konsumen".Skripsi Fakultas Ekonomi Universitas Muhammadiyah Gresik.

Nurhayati Risky. 2011, "Pengaruh Kualitas Produk Dan Harga Terhadap Loyalitas Pelanggan"Jurusan Ilmu Administrasi BisnisFakultas Ilmu Sosial Dan Ilmu PolitikUniversitas Pembangunan Nasional "Veteran"Yogyakarta.

Nursanah. 2010, "Analisis Pengaruh Keragaman Produk,Kualitas Pelayanan dan Kepuasan Pelanggan Terhadap Loyalitas Pelanggan Pada PT. Hiro Supermaket Taronggong Cilandak" Skripsi Fakultas Ekonomi Universitas Islam Negeri Syarif Hidayatullah Jakarta.

Saputro, Agung Dwi. 2014, "pengaruh harga, keragaman produk, fasilitas dan atmosfer kenyamanan terhadap motif belanja konsumen di UD.Sarikat Jaya Gresik"'Skripsi Fakultas Ekonomi Universitas Muhammadiyah Gresik.
Schiffman dan Kanuk. 2008. Perilakukonsumen. Edisi 7. Jakarta: Indeks.

Sugiyono, 2010 , Statistika Untuk Penelitian Bisnis, Bandung. Alfabeta.

Utami, Whidya Christina. 2006, manajemen ritel:strategi dan implementasi ritel modern,Salemba Empat, Jakarta. 2014, manajemen ritel:strategi dan implementasi operasional bisnis ritel modern di indonesia. Edisi Dua, Salemba Empat, Jakarta. 